\title{
Compromised or Savvy? Achievable Norms in Urban Design
}

\section{Citation}

Forsyth, Ann. 2013. "Compromised or Savvy? Achievable Norms in Urban Design." Journal of Urban Design 19 (1) (December 10): 44-46. doi:10.1080/13574809.2013.854679. http:// dx.doi.org/10.1080/13574809.2013.854679.

\section{Published Version}

doi:10.1080/13574809.2013.854679

\section{Permanent link}

http://nrs.harvard.edu/urn-3:HUL.InstRepos:16242627

\section{Terms of Use}

This article was downloaded from Harvard University's DASH repository, and is made available under the terms and conditions applicable to Open Access Policy Articles, as set forth at http:// nrs.harvard.edu/urn-3:HUL.InstRepos:dash.current.terms-of-use\#OAP

\section{Share Your Story}

The Harvard community has made this article openly available.

Please share how this access benefits you. Submit a story.

\section{Accessibility}




\section{Compromised or Savvy? Achievable Norms in Urban Design}

Ann Forsyth

Harvard University

2014 Journal of Urban Design 19, 1: 44-46

Theories of urban design often propose what is good. The various isms-modernism, new urbanism, landscape urbanism - are replete with charters and pronouncements of this kind. Good urban design is also a theme in a wide range of more general texts from Lang to Lynch, Alan Jacobs to Jane Jacobs. Carmona's new place-shaping continuum tries a different appoach,proposing a theory of achievable urban design. Given the typical range of people involved in initiating, funding, regulating, building, using, and managing urban design outputs, who has most influence over completed projects and at what stages? Where are the key points of intervention-including but going far beyond initial design ideas?

Carmona proposes this is a new kind approach to urban design theory focused on the process of design rather than its products. Such a claim of newness raises a number of questions. Is it new? Whether or not it is new, is it a useful theory? Is this kind of procedural theory a compromised approach lacking idealism, or a politically savvy view sensitive to the multiple constituencies involved in design? Does it represent the insidious influence of planning theory-that over time has come to focus on politics and process as well as ethics or norms? Or is it a logical opening up of urban design theories focused on form and perception to the crucial issue of implementation?

In making his argument, Carmona draws from a variety of sources. Like many classic works in urban design he uses place-specific observations including a wide survey and deeper case studies of contemporary public spaces in London. It is also a study embedded in a wider review of the state of scholarship in urban design in North America and Europe. Carmona focuses, however, on a somewhat neglected area in urban design - the issue of implementing urban design projects. To do this he sees projects not merely as design ideas or finished places but as a series of events-a process of placeshaping--from inception to management and use.

Public spaces - particularly the semi-enclosed squares and yards that make up most of Carmona's detailed cases - have long been a major focus of urban design activity. Carmona is right that many works in this area have paid attention to one aspect of the public space creation process such as design or use. On the other hand larger projects beg the question of process more starkly and have allowed a number of authors to examine the wider context of design visions and products over time. A few examples provide a flavor of how urban design has been analyzed in context-moving from inception through design, use, and management.

- $\quad$ Crewe (2001) looked not at one public space but a trail linking multiple spaces and a transit corridor over almost five miles. Using interviews, archives, and observations she describes a design and planning process spanning a decade and involving, in some estimates, a tenth of the population of Boston. Centrally concerned with the effects of participation on design quality, Crewe's study provides a nuanced view of the process, including strengths and weaknesses from the views of multiple community and professional participants. She concludes that it had complicated effects on design quality but led to an increased sense local ownership of the space, eventually fostering voluntary maintenance of the areas.

- Gordon's (1997) treatment of Battery Park City: Politics and Planning on the New York Waterfront provides an extended case study of the interplay of design, planning, and politics in this high profile mixed-use development in the core of a major city. With a similar sensibility to 
that demonstrated by Carmona, he focuses on the interactions between design options, political processes, and planning activities and even uses a similar language of tradeoffs and management.

- My own (2005) book, Reforming Suburbia: the Planned Communities of Columbia, Irvine, and The Woodlands, is of this genre examining three 1960s and 1970s new towns from inception, through design, development, and inhabitation over some decades. Again, in these large, long-running, and complex projects the iterative character of design decision making and implementation is clear. This is the case even though I selected the three locations because they had particularly strong initial concepts, pioneering many smart growth and compact city ideas, implemented with a high level of consistency over time.

Such works show that the mere fact of considering the interplay of design, planning, politics, development, use, and management is one with some tradition in urban planning and design. And this is particularly the case for those looking at larger and more complex projects over time where the power of these multiple factors is inescapable.

What does Carmona add? One element is a self-conscious attempt to create a general theory of urban design. Another is to propose a more complex procedural view of urban design as an alternative to theories that emphasize the process of developing a design idea or the goodness of the idea itself. Of course, Carmona's is not an entirely procedural theory, as I'm sure he'd admit, but rather one focused on achievable norms or the interaction between design norms and context over time.

This is to be commended for adding sophistication to the field of urban design and helping designers understand the limits to the power of initial design ideas as they interact with economic forces, government priorities, and user activities. It unpacks several parts of design. It deals with the changing, and not static, context of urban design through the life of the project. In the end is it very new? Not really. Is it useful? I think it is, in engaging with implementation, as well as vision, it highlights key dimensions of urban design.

Crewe, K. 2001. The quality of participatory design: The effects of citizen input on the design of the Boston Southwest Corridor. Journal of the American Planning Association 67, 4: 437-455.

Gordon, D. 1997. Battery Park City: Politics and Planning on the New York Waterfront. New York: Gordon and Breach/Routledge.

Forsyth, A. 2005. Reforming Suburbia: The Planned Communities of Irvine, Columbia, and The Woodlands. Berkeley, CA: University of California Press. 